\title{
Rodzina jako podmiot przedsiębiorczy - krytyczna analiza dyskursu wychowania małego geniusza w portalach internetowych dla rodziców
}

\author{
KEYWORDS \\ infant prodigy, parents \\ internet portals, \\ professionalization of \\ parenting, \\ entrepreneurship \\ discourse, critical \\ discourse analysis
}

\begin{abstract}
Popow Monika, Rodzina jako podmiot przedsiębiorczy - krytyczna analiza dyskursu wychowania małego geniusza w portalach internetowych dla rodziców [Family as Enterprising Subject - Critical Analysis of the Infant Prodigy Discourse in Internet Portals for Parents]. Kultura Społeczeństwo - Edukacja nr 2(6) 2014, Poznań 2014, pp. 95-118, Adam Mickiewicz University Press. ISBN 978-83-232-2869-1. ISSN 2300-0422

The aim of this paper is to analyse the infant prodigy discourse in popular Polish internet portals for parents. As a result of Critical Discourse Analysis, key rhetoric strategies, constructing the representation of a child and its family, have been identified. Subsequently, the analysis of particular discursive strategies, including professionalization of parenthood and discursive construction of a family as an entrepreneur of the self, have been conducted.
\end{abstract}

Na polskim rynku wydawniczym znaleźć można dużą liczbę poradników dla rodziców. Rosnąca popularność, a także wielość publikacji oraz poruszanych przez nie tematów pozwala przypuszczać, że polscy rodzice chętnie czerpią z poradników wiedzę na temat wychowania. Rola poradników niewątpliwie wzrasta, co przypisać można poczuciu niepewności, jaka - zdaniem Zygmunta Baumana towarzyszy naszym czasom (Bauman, 2007) Jak zauważa w tym kontekście Edyta Zierkiewicz, w świecie, w którym każda sfera życia podlega nieustannym zmianom, poradniki pełnią dla niektórych osób funkcję przewodników po życiu (Zierkiewicz, 2011: 110).

Obok tradycyjnych publikacji, prężnie rozwija się rynek portali internetowych przeznaczonych dla rodziców (tzw. serwisy parentingowe). Podobnie jak inne 
wydawnictwa, mają one rozbudowane działy tematyczne, a ponadto dają swoim czytelnikom możliwość komentowania, budowania społeczności czy też pisania blogów na temat wychowania dzieci. Serwisy parentingowe posiadają już setki tysięcy użytkowników i stają się jednym z najszybciej rozwijających się rodzajów portali tematycznych. Wystarczy wspomnieć, że już w 2011 roku, według raportu PBI, korzystało $\mathrm{z}$ nich pięć milionów osób ${ }^{1}$, i liczba ta ciągle wzrasta.

Jednym $\mathrm{z}$ najczęściej pojawiających się tematów $\mathrm{w}$ mediach przeznaczonych dla rodziców, zarówno tradycyjnych, jak i internetowych, jest wychowanie rozwijające zdolności dzieci. Dużo miejsca poświęca się kwestii wychowania dziecka na „małego geniusza”, który osiągać będzie sukcesy w szkole, a w przyszłości - w pracy zawodowej.

Już pobieżny przegląd prasy parentingowej pokazuje, że „wychowaj małego geniusza" to jedno $\mathrm{z}$ najbardziej nośnych $\mathrm{w}$ naszym kraju edukacyjnych haseł ostatnich lat. Jego popularność niewątpliwie związana jest ze wzrostem aspiracji edukacyjnych Polaków. W ostatnich latach odnotowuje się lawinowy wzrost specjalnych programów edukacyjnych oraz ofert zajęć mających na celu pomoc dzieciom w rozwoju talentów. W Internecie znaleźć można niezliczone artykuły poświęcone metodom oddziaływań wychowawczych, które sprawią, że dziecko wyrośnie na błyskotliwego odkrywcę, przed którym świat stanie otworem. „Bycia geniuszem można się nauczyć” - przekonują media i reklamy szkół. W XXI wieku kształcenie małego geniusza zależy od zaplanowanego rozwoju i kształcenia.

Popularność tematyki oraz wielość artykułów jej poświęconych zachęca do przyjrzenia się dyskursowi wychowania małego geniusza $w$ artykułach skierowanych bezpośrednio do rodziców i zamieszczonych w najpopularniejszych polskich portalach internetowych poświęconych kwestii wychowania dzieci. Celem niniejszej analizy będzie odpowiedź na pytania: $\mathrm{w}$ jaki sposób w dyskursie małego geniusza kreowane są role i wizerunek dziecka oraz jego rodziców, jakie dyskursy je tworzą oraz jakie mają one społeczne i kulturowe znaczenie?

\section{Kategoria geniusza w perspekływie kulturowej}

Postać Wunderkinda, wybitnego dziecka, którego cudowne zdolności budzą podziw, na trwałe wpisała się do kultury popularnej, chociaż genialne dzieci funkcjo-

\footnotetext{
${ }^{1}$ Serwisy parentingowe w Polsce: zawartość serwisów, popularność wśród internautów, profil użytkowników, Polskie Badania Internetu, luty 2011; http://pbi.org.pl/raporty/Serwisy_parentingowe.pdf (dostęp: 01.10.2014 r.).
} 
nowały w kulturze dużo wcześniej - wystarczy wspomnieć małego Mozarta. Współcześnie media wielokrotnie opisują historie małych studentów kończących najlepsze uczelnie na świecie z pierwszymi lokatami.

W kulturze popularnej na trwałe zadomowili się nastoletni lekarz Doogie Howser, bohater amerykańskiego serialu dla młodzieży, oraz posiadający niezwykłe zdolności czarodziej Harry Potter.

Pojęcie małego geniusza wywodzi się z koncepcji geniusza, która funkcjonuje w kulturze europejskiej od czasów starożytności. W filozofii i historii sztuki rozwijana była ona przez stulecia, będąc nieodłącznym elementem rozważań z zakresu estetyki.

Ze względu na ograniczoną objętość, niemożliwe jest uwzględnienie w niniejszym tekście historycznej rekonstrukcji koncepcji geniusza. Przytoczyć można jedynie wybrane ujęcia oraz związany z nimi kontekst społeczno-kulturowy. Interesujące są również współczesne dekonstrukcje pojęcia geniusza, które miały wpływ na obowiązujące obecnie pojmowanie roli jednostki oraz jej talentu. $Z$ tego też powodu przegląd rozpocząć należy od epoki romantyzmu, w której rozwinął się kult wielkiej jednostki, naznaczonej darem twórczości oraz przywództwa. Romantyczny geniusz, symbolizowany przez postaci Napoleona, Beethovena czy Goethego, na trwale wpisał się do historii kultury. Można wręcz powiedzieć, że przez dwa stulecia romantyczna figura geniusza rządziła, a w niektórych kontekstach rządzi nadal, zbiorową wyobraźnią (Skórczewski, 2010: 118). Romantyczny geniusz należał do sfery niemalże boskiej, dostępnej jedynie dla wybrańców, zamkniętej natomiast dla zwykłych śmiertelników. Geniusz jest w tym ujęciu kategorią na poły mityczną, na poły natomiast boską, zgodnie $\mathrm{z}$ chrześcijańskim rozumieniem genialności jako daru od Boga (Kasperski, 2012: 12).

Dopiero w drugiej połowie XX wieku koncepcja geniusza poddana została krytyce, między innymi przez feminizm. W eseju Dlaczego nie było wielkich artystek? Linda Nochlin przekonywała: „Za pytaniem o kobiety artystki kryje się więc mit Wielkiego Artysty - istoty wyjątkowej, obdarzonej boskimi cechami, bohatera setek monografii - który od urodzenia nosi w sobie tajemniczą esencję, niczym grudkę najczystszego złota. Owa tajemnicza esencja, zwana Geniuszem lub Talentem, jak morderstwo zawsze wyjdzie na jaw, nawet w najbardziej nieprawdopodobnych bądź niesprzyjających okolicznościach” (Nochlin, 2007). Krytyka ta, nawiązująca do kwestii braku w historii sztuki znanych postaci genialnych malarek, wskazuje na społeczno-kulturowe uwarunkowania pojęcia genialności, ukryte za jego mitologizacją, oraz praktykę przypisywania tej cechy osobom posiadającym dostęp do zasobów, przede wszystkim do edukacji. 
W obrębie nauk społecznych na koncepcję geniusza warto spojrzeć poprzez teorię Pierre'a Bourdieu. Jak przytacza David Harris, w badaniach nad szkolnictwem wyższym, które Bourdieu przeprowadził wraz ze swoim zespołem, zaobserwowano, że postawa romantycznego twórcy, który w swobodny i lekki sposób kreuje swoją pracę, jest ceniona wyżej niż postawa zakładająca ciężką pracę. Badani studenci z klasy wyższej oraz profesorowie przyjmowali częściej postawę romantycznego twórcy, stojącą $\mathrm{w}$ opozycji do zajmowania się rzeczami przyziemnymi (Harris, 2013: 414). Biorąc pod uwagę fakt, że ciężka praca, nawet intelektualna, ma symboliczne konotacje z klasą robotniczą, postrzeganą - jak wykazuje Bourdieu - jako nieposiadająca wystarczającego kapitału społecznego oraz naturalnych predyspozycji, preferowany wizerunek naturalnie uzdolnionej i inteligentnej jednostki może być interpretowany jako jeden $\mathrm{z}$ wyrazów przemocy symbolicznej oraz budowania relacji klasowych (Harris, 2013: 414).

Analiza dyskursu naturalnych zdolności i predyspozycji ma również ugruntowaną pozycję w pedagogice krytycznej. Douglas E. Allen i Paul F. Anderson zwracają, za Bourdieu, uwagę, że w szkole, która jest ważną agendą reprodukcji klasowej, nieobiektywne $\mathrm{w}$ gruncie rzeczy kategorie talentu wykorzystywane są do reprodukowania nierówności społecznych. Szkoła częściej bowiem niż „utalentowanych" przedstawicieli mniejszości etnicznych, rasowych czy klasy robotniczej, promuje wysoki kapitał kulturowy (Allen, Anderson, 1994: 70-74).

Koncepcja talentu, naturalnych predyspozycji i geniusza spotkała się też z podobną krytyką ze strony teorii postkolonialnej. Teoretycy związani z tym nurtem zwrócili uwagę na europocentryczność kategorii geniusza, która, podobnie jak racjonalny rozum, budowana jest $\mathrm{w}$ oparciu o wyłącznie europejskie doświadczenie kulturowe (Ghandi, 2008: 42-43). Współcześnie w amerykańskich badaniach zwraca się również uwagę na ukryty przekaz rasistowski oraz klasowy, jaki stoi za koncepcjami naturalnych uzdolnień oraz predyspozycji. Geniuszami w zakresie sztuki, literatury czy też nauk ścisłych są zazwyczaj osoby białe. Osoby kolorowe, przede wszystkim czarnoskóre, mogą być natomiast co najwyżej geniuszami w sporcie (Wagg, 2005). Symbolicznie pokazuje to relacje władzy w społeczeństwie, w którym możliwości awansu dla osób z marginalizowanych grup etnicznych i klas społecznych są ograniczone do określonego zestawu działań, najczęściej związanych $\mathrm{z}$ aktywnością fizyczną.

W kontekście polskim jednym z najbardziej znaczących zastosowań kategorii talentu i geniusza jest ich obecność w dyskursie neoliberalnym, opierającym się przede wszystkim na koncepcji Richarda Floridy, autora głośnej książki Narodziny 
klasy kreatywnej. Florida odmitologizował bowiem geniusza, stawiając jego, do tej pory nadludzkie, umiejętności $\mathrm{w}$ szeregu tych, które każdy, jeśli tylko chce, może osiągnąć. Nazwał je kreatywnością, która, według niego, jest zdolnością właściwą każdemu praktycznie człowiekowi (zob. Florida, 2010). Florida zrzucił geniusza z piedestału, a na jego miejsce postawił klasę kreatywną, ludzi wolnych i twórczych, którzy dzięki własnym chęciom i talentowi popchnąć mogą świat ku nowoczesności.

Koncepcja Richarda Floridy ma duże znaczenie dla obecnego pojmowania talentu, zdolności, a także geniusza. W koncepcjach neoliberalnych talent stał się wyznacznikiem wysoko wyspecjalizowanej klasy rządzącej, nazywanej właśnie klasą kreatywną. Stał się również podstawą dyskursu braku ograniczeń, promującego przedsiębiorczość i odpowiedzialność jednostki za własne życie. Krytycy tego podejścia, jak na przykład Can Sancar i Mine Sancar, zwracają uwagę na fakt, że filozofia ta promuje skrajny indywidualizm, wykluczający słabość czy niedoskonałość, oraz całkowicie przenosi na jednostkę odpowiedzialność za wszelkie działania w sferze materialnej i emocjonalnej. Według nich, w świecie, w którym każdy odpowiedzialny jest za rozwój swojego talentu, prawa dyktuje wyłącznie logika konkurencyjności (Sancar, Sancar, 2012).

W tym kontekście istotnym wydaje się, że - jak podaje Danuta Michałowska neoliberalizm zakłada, jako naturalne, genetyczne i społeczne zróżnicowanie kapitałów (Michałowska, 2013: 239). Idąc tym tropem, warto zauważyć, że w neoliberalizmie mówi się o istnieniu nierówności, których likwidacja jest niemożliwa, albowiem są one częścią porządku świata. Podobnie postrzegane jest zróżnicowanie talentów, predyspozycji i umiejętności, które wyposażone w nie jednostki mają prawo (i wolność) rozwijać w nieskrępowany sposób. Można wysnuć wniosek, że bycie geniuszem, czy też posiadanie talentu, jest zatem w filozofii neoliberalizmu pożądane, gwarantuje bowiem sukces zarówno zawodowy, jak i prywatny.

Ten krótki przegląd rozwoju pojęcia geniusza nie wyczerpuje oczywiście wszystkich znaczących koncepcji, pozwala jednak zarysować współczesną ewolucję samego pojęcia oraz przedstawić w szerszej perspektywie dyskurs wychowania małego geniusza, którego analiza jest celem mojego tekstu.

Analizie poddane zostały artykuły zamieszczone w trzech najpopularniejszych - według rankingu portalu Wirtualne Media - portalach internetowych dla rodziców. Są to: Onet Dziecko, Dzieci.pl oraz e-dziecko.pl ${ }^{2}$. Aby pokazać fenomen dyskursu wychowania małego geniusza, przeanalizowanych zostało kilkadziesiąt arty-

${ }^{2}$ Onet Dziecko, Dzieci.pl i eDziecko.pl na czele, $w$ dół Rodzice.pl i Dobramama.pl (TOP15 serwisów parentingowych), Wirtualne Media, 16.05.2014, http://www.wirtualnemedia.pl/artykul/onet-dziecko-dziecipl-i-edziecko-pl-na-czele-w-dol-rodzice-pl-i-dobramama-pl-top15-serwisow-parentingowych (dostęp: 18.05.2014 r.). 
kułów oraz wypowiedzi eksperckich z lat 2009-2013³. Wybór mediów internetowych wynika z jednej strony z przytoczonych w cytowanym wyżej raporcie Serwisy parentingowe $w$ Polsce: zawartość serwisów, popularność wśród internautów, profile użytkowników danych na temat ich popularności, z drugiej zaś z przekonania, iż współcześnie media internetowe, dając możliwość udostępniania artykułów poprzez portale społecznościowe oraz telefony komórkowe wraz z opcją budowania społeczności oraz komentowania, oddziaływać mogą z coraz większą siłą. Ponadto, ich treści osiągalne są również dla osób, które nie chcą lub nie mogą zapłacić za poradnik wydany $w$ tradycyjnej formie.

W artykule zastosowana została metoda krytycznej analizy dyskursu, będąca, jak definiują ją Anna Duszak i Norman Fairclough: „analizą procesów społecznych, skupiającą się głównie na ich wymiarach semiotycznych - innymi słowy, jest to semiotyczny punkt wejścia w procesy społeczne, które są wewnętrznie ukonstytuowane jako dialektyczne relacje między rozmaitymi elementami i momentami społecznymi, obejmującymi dyskurs i momenty dyskursywne" (Fairclough, Duszak, 2008: 15).

Zastosowana została metoda analizy przekazów medialnych według schematu George'a Gerbnera, uwzględniająca pojawianie się lub brak pewnych problemów i tematów, nadawanie priorytetu pewnym tematom, przypisywanie określonych wartości, kontekst strukturalny wypowiedzi ${ }^{4}$.

Przeprowadzając analizę, przyjęto, że krytyczna analiza dyskursu wychowania małego geniusza pozwoli mi przyjrzeć się nie tylko retorycznym strategiom konstruowania wizerunku małego geniusza oraz jego otoczenia, w tym rodziców, ale również odnieść się w szerokim kontekście społecznym do procesów dyskursywnego konstruowania tożsamości, w tym wypadku - dziecka i rodziców.

\section{Jak wyhodować małego geniusza?}

Dziecko tradycyjnie znajduje się w centrum zainteresowania pedagogiki. Historia wychowania pokazuje, że podejście do samego dziecka, jak również celów jego wychowania, zmieniały się w czasie, rozwijając się w stronę koncepcji upodmiota-

\footnotetext{
${ }^{3}$ Dostęp do wszystkich artykułów uzyskany został w dniach 18-25.05.2014 r., a następnie ponownie sprawdzony w dniu 31.05.2014 r. W dalszej części tekstu data dostępu nie jest podawana. Nazwisko autorów analizowanych artykułów przytaczane jest w przypadkach, gdy zostało podane.

${ }^{4}$ Metoda zaczerpnięta na podstawie artykułu: K. Sztop-Rutkowska, Meandry dialogu. Polacy i Żydzi w dyskursie prasowym międzywojennego Białegostoku, „Przegląd Socjologii Jakościowej” 2007, nr 2(3).
} 
wiających dziecko. Poszczególne filozoficzne ujęcia wychowania - od koncepcji klasycznych poprzez koncepcje pajdocentryczne aż po nurty antyautorytarne i antypedagogiczne rozwijane w XX wieku, nazywanym stuleciem dziecka - radykalnie różniły się w sposobie patrzenia na cele wychowania.

Zagadnienie specjalnych potrzeb edukacyjnych dziecka zdolnego jest również szeroko rozwijane w pedagogice oraz psychologii. Literatura przedmiotu koncentruje się przede wszystkim na kwestii stworzenia warunków sprzyjających rozwojowi zdolności, a także problemów i barier, z jakimi stykać może się dziecko zdolne, zwłaszcza problemów przyspieszonego rozwoju (zob. Kozyra-Cieślak, 2012; Dyrda, 2000; Limont, Cieślikowska, Jastrzębska, 2012).

Ostatnie kilkadziesiąt lat przyniosło zasadniczą zmianę w postrzeganiu dziecka oraz społeczno-kulturowego kontekstu jego funkcjonowania. Jest on rozumiany nie tylko jako zmienny w czasie, miejscu i przestrzeni, ale również uwarunkowany szeregiem czynników społecznych, w tym relacjami władzy w obrębie społeczeństwa. Perspektywie tej towarzyszy rozwój badań pokazujących różnorodność dyskursów stosowanych współcześnie w procesie wychowania. Dorota Klus-Stańska, kierując się kryterium postrzegania dziecięcych kompetencji, wyróżniła sześć kategorii dyskursów. Pierwszy to dyskurs systemu z deficytami, w ramach którego dziecko jest niezapisaną kartą, wdrażaną w procesie wychowania we właściwe zachowania. Następny z wyróżnionych dyskursów to dyskurs słodkiego elfa, którego beztroskie dzieciństwo chronić mają dorośli. Trzeci to dyskurs infantylnego badacza, poznającego świat poprzez swoje ograniczone, dziecięce kategorie w ramach bezpiecznej przestrzeni do eksperymentowania, którą organizują dla niego dorośli. Kolejnym jest dyskurs aktywnej niepełnosprawności - dziecko wymaga tutaj ukierunkowanej pomocy dorosłego. Następnie Klus-Stańska wyróżniła dyskurs demiurga/konstruktora, który tworzy własne koncepcje świata oraz pokonuje trudności, i wreszcie dyskurs kontestatora, uczącego się w procesie angażowania się w różne sprawy oraz zabierania głosu (Klus-Stańska, 2008: 59-73).

Wydaje się, że spośród typów wyróżnionych przez Dorotę Klus-Stańską dyskursowi wychowania małego geniusza najbardziej odpowiada dyskurs demiurga/konstruktora. Mały geniusz, którego wizerunek wyłania się $\mathrm{z}$ analizowanych tekstów, to dziecko pomysłowe, aktywne i niesprawiające kłopotów wychowawczych. Posiada swoje pasje i zainteresowania, efektywnie wykorzystuje każdą chwilę.

Dzisiejszy Wunderkind nie jest już małym naukowcem, odstającym od rówieśników, zamkniętym w hermetycznym świecie nauki i eksperymentów. Do takiego wizerunku małego geniusza, który prosto z przedszkola trafia na studia, przyzwy- 
czaiła nas kultura popularna. Współczesny mały geniusz jest dzieckiem uzdolnionym, które swój talent z powodzeniem wykorzystać może w różnych dziedzinach życia. Dyskurs wychowania małego geniusza, zawarty w analizowanych portalach parentingowych, przedefiniowuje dawne elitarne pojęcie geniusza, określając $w$ ten sposób wysoki poziom rozwoju intelektualnego dziecka.

W analizowanych artykułach wychowanie dziecka zdolnego odbywa się w każdej sferze życia. Rodzice otrzymują przykłady działań, jakie mogą realizować, aby wpływać na rozwój swojego dziecka. Warto przytoczyć kilka przykładów:

Dajmy dzieciom szansę wyjść poza utarte schematy, wspierając poszukiwanie rozwiązań, np. podczas zabawy. Zadawajmy mnóstwo pytań: Co by było, gdyby wszyscy ludzie chodzili na czterech kończynach? Co by było, gdyby na świecie nie istniały pieniądze? ${ }^{5}$

Nic lepiej nie przekonuje niż zasłyszane lub przeczytane opinie innych mam. Natalia, mama prawie trzyletniej Mai i pięciomiesięcznego Kostka, zaczęła naukę liczenia ze swoimi dziećmi. Okazało się, że kropki fascynują córkę, a na synka wpływają uspokajająco (...). Rzeczywistość pokazała, że Maja w sposób dynamiczny domagała się większej ilości kart z kropkami, a Kostek ze swojego leżaczka zafascynowanym wzrokiem chłonął zarówno to, co widział na kartach, jak i to, jak zachowywała się jego siostra ${ }^{6}$ :

Działania związane $\mathrm{z}$ wychowaniem małego geniusza nie są przypadkowe. Rodzice przypisują tu swojemu działaniu konkretne znaczenie edukacyjne, a przed swoimi dziećmi, nawet jeśli są one jeszcze niemowlętami, stawiają konkretne zadania.

Dyskurs poradników na temat małego geniusza oraz wchodzące w jego zakres zagadnienie wychowania dziecka zdolnego konstruowane są wokół pojęcia rozwoju. Słowo to jest jednym $\mathrm{z}$ najczęściej pojawiających się $\mathrm{w}$ analizowanym materiale i dotyczy każdej praktycznie sfery życia: mowa jest zatem o rozwoju społecznym, intelektualnym, emocjonalnym czy neurologicznym. Dopełniają go następujące czasowniki: wpływać, stymulować, wspierać, wspomagać, a wreszcie inwestować, co odsyła do skojarzeń z ekonomią i przedsiębiorczością. Wychowanie stanowi w dyskursie poradników wręcz projekt rozwojowy, który realizowany jest przez rodzinę i szkołę.

Ważną cechą dyskursu kształtowania młodego geniusza jest tegoż geniusza racjonalność. Artykuły zachęcają do zachowania umiaru i liczenia się z możliwo-

${ }^{5}$ Jak wychować geniusza?, 17.02.2011; http://dzieci.pl/gid,13138964,img,13138992,title,Jak-wychowacgeniusza,galeria.html.

${ }^{6}$ Jak nauczyć niemowlaka liczyć?, 11.01.2010; http://kobieta.onet.pl/dziecko/niemowle/jak-nauczycniemowlaka-liczyc/z61zr. 
ściami dziecka („nie chodzi o restrykcyjne wychowywanie dziecka na geniusza”). Oddziaływania wychowawcze, jakie mają zastosować rodzice, należy zatem dawkować, a nawet podchodzić do nich $\mathrm{z}$ dystansem. Analizowane artykuły pełne są historii dzieci-menadżerów z przepełnionym grafikiem oraz historii trzylatków zmuszanych do gry na skrzypcach. Poradniki nie pochwalają przymuszania dziecka do nauki, zamiast tego postulują holistyczne podejście do rozwoju talentu. Wydaje się, że źródła koncepcji wychowania zawartej w analizowanych portalach znajdują się w myśli Jana-Jakuba Rousseau, który w słynnym traktacie Emil, czyli o wychowaniu postulował rozwijanie wiedzy wychowanka poprzez jego własne doświadczenia (zob. Rousseau, 1955). Czerpiąc pewne elementy z koncepcji Rousseau dotyczącej wychowania, poradniki skupiają się nie na całościowym rozwoju, lecz przede wszystkim na rozwoju talentu dziecka, i postulują, aby kształtować go przy okazji codziennych zabaw, doświadczeń, eksperymentowania oraz w zgodzie $\mathrm{z}$ naturą. Potwierdzają to cytowani eksperci:

Dla nas jest ważniejsze, aby trzylatki długo przebywały na świeżym powietrzu albo zobaczyły, jak lepi się pierogi, zamiast spędzania kilka godzin na słuchaniu wykładu poświęconego astronomii - tłumaczy [pracownica przedszkola - M.P.]. Wprawdzie w przyprzedszkolnym żłobku niemowlęta zgłębiają tajniki angielskiego, ale nauka odbywa się mimochodem, przy okazji innych zajęć i zabaw. Hennig Scheich, profesor neurobiologii w Instytucie Leibnitza w Magdeburgu, potwierdza, że maluchy mają ogromne predyspozycje do nauki języków obcych, pod warunkiem, że danym językiem posługują się członkowie rodziny albo wychowawczyni w przedszkolu?

Rozwój geniusza następuje tutaj jakby przy okazji, tak naprawdę jest jednak szczegółowo zaplanowanym procesem. Pedagodzy i rodzice wypowiadający się $\mathrm{w}$ analizowanych artykułach skupiają się na wypełnianiu zadań wychowawczych, podkreślając, że ważne jest zachowanie umiaru.

Uwagę zwraca medykalizacja dyskursu wychowania, w którym często stosowane są kategorie związane z biologią, medycyną oraz psychologią, na przykład:

Mózg dziecka kształtuje się w pierwszym miesiącu ciąży, a już od chwili narodzin maluch przyswaja niezwykle dużo informacji. Z minuty na minutę zdobywa coraz więcej umiejętności, a wszystkie procesy poznawcze w jego mózgu odbywają się w zaskakująco szybkim tempie. Potencjał małego geniusza warto więc wykorzystać już od pierwszych chwil życia... a następnie stale pielęgnować8.

${ }^{7}$ Jak wychować geniusza?, op. cit.

${ }^{8} \mathrm{Na}$ co zwrócić uwagę, chcac rozwijać talent malucha?, 25.04.2012, http://kobieta.onet.pl/dziecko/ male-dziecko/na-co-zwrocic-uwage-chcac-rozwijac-talent-malucha/dmj0p. 
Dyskurs wychowania małego geniusza naszpikowany jest słownictwem związanym $\mathrm{z}$ anatomią oraz neurologią. Opisywany jest jego odmiennie funkcjonujący mózg oraz system nerwowy, co podkreśla nie tylko wyjątkowość dziecka, ale również jego biologiczną odmienność:

Mówiąc bardzo ogólnie, lewa półkula mózgowa, analityczna, odpowiada za logiczne rozumowanie, a prawa, intuicyjna, za odczytywanie informacji zawartych w obrazach i kojarzenie. - To właśnie dlatego myślenie dziecka wybitnie uzdolnionego jest globalne i wielowątkowe - twierdzi pani Siaud-Facchin. - Informacja przechodzi przez cały mózg, powodując kojarzenie różnych myśli, które bardzo szybko się zazębiają (...). Inną ważną cechą, która odróżnia takie dzieci od innych, jest ich nadaktywność emocjonalna, spowodowana szczególną wrażliwością ciała migdałowatego (neurony w naszym mózgu położone w okolicach płata skroniowego) - tłumaczy psycholożka. Nawet drobne zajście może wywołać u takiego ucznia emocjonalny kryzys. - Jedyną metodą, by uspokoić malca, jest dotknięcie go, pogłaskanie. Żadne wyjaśnienia tu nie pomogą zapewnia specjalistka9 .

W tym wypadku dyskurs biologicznej odmienności legitymizowany jest poprzez autorytet ekspertki, która w formie naukowego wykładu tłumaczy, czym szczególnie zdolne dziecko różni się od rówieśników pod względem biologicznym. Jej wypowiedź zawiera słownictwo specjalistyczne, związane ze sferą medycyny, co sprawia, że nabiera ona wiarygodności. Wskazuje to na jeszcze jedną cechę analizowanego dyskursu, a mianowicie jego unaukowienie. Zjawisko to charakteryzuje się włączeniem w obręb dyskursu wychowania - dyskursu naukowego, najczęściej z nauk zakresu ścisłych, psychologii, biologii, co służy legitymizacji produkowanej w ten sposób wiedzy, w tym wypadku na temat wychowania. Unaukowienie wiedzy sprawia, że staje się ona pewna, autorytet ekspertów natomiast - niepodważalny.

Co ciekawe, poradniki pokazują też, że biologiczny rozwój genialnego dziecka można stymulować, na przykład poprzez podawanie odpowiednich posiłków czy też utrzymywanie odpowiedniej diety, która pobudza rozwój mózgu ${ }^{10}$.

Medykalizacja i unaukowienie dyskursu wychowania małego geniusza, a zwłaszcza wątek biologicznej odmienności, przywodzą na myśl dyskursywne zabiegi urasawiania, na które zwraca uwagę Monika Bobako (2011). Według niej, służą one naturalizowaniu cech przypisywanych danej grupie społecznej, tworząc w ten sposób ich dyskursywne charakterystyki. Praktyki te mają najczęściej na celu legitymi-

${ }^{9}$ Geniusze specjalnej troski, 10.01.2010; http://kobieta.onet.pl/dziecko/starsze-dziecko/geniuszespecjalnej-troski/6fpel.

${ }^{10}$ Dieta przyszłego geniusza, 25.01.2013; http://dzieci.pl/kat,1033627,page,2,title,Dieta-przyszlegogeniusza, wid,15285067, wiadomosc.html? smgputicaid=612c69. 
zację nierówności społecznych poprzez uwypuklenie, pokazywanych jako naturalne, różnic. Taką funkcję pełni na przykład dyskurs błękitnej krwi, którego celem było wprowadzenie rozróżnienia pomiędzy arystokracją a niższymi warstwami społecznymi (Bobako, 2011: 2).

W przypadku dyskursu wychowania małego geniusza mamy wyraźnie do czynienia $\mathrm{z}$ konstruowaniem wizerunku dziecka biologicznie odmiennego, w stosunku do którego podejmować należy inne działania niż w stosunku do zwykłych dzieci. Mali geniusze to w dyskursie poradników osobny gatunek dzieci, wręcz osobna rasa, z którą trzeba nauczyć się postępować.

Co istotne jednak, wysoka inteligencja nie jest przedstawiana jako dziedziczona genetycznie. Większość artykułów koncentruje się na problemie przeprowadzenia przez rodziców prawidłowej diagnozy - rozpoznaniu geniusza, a następnie zastosowaniu odpowiedniej procedury wychowawczej. Można zatem sformułować tezę, że w dyskursie poradników geniusz może urodzić się w każdej rodzinie, zadaniem rodziców natomiast jest odpowiednie rozpoznanie i skuteczne wychowanie dziecka zdolnego:

Genialne dziecko może pojawić się jak meteor w każdej rodzinie i rozbłysnąć talentem na dowolnym polu (...). Dziecko wzrasta w stymulującej atmosferze, ale nie jest zmuszane ani nawet nakłaniane do nauki, uczy się z własnej i nieprzymuszonej woli i pędzi do przodu, a rodzice starają się za wszelką cenę dotrzymać geniuszowi kroku ${ }^{11}$.

Równocześnie poradniki zdają się obiecywać, że dzięki właściwemu wychowaniu każde dziecko osiągnąć może sukces. Nawet jeśli nie jest wybitnie zdolne, może rozwinąć drzemiące w nim talenty, a w przyszłości osiągnąć dzięki temu dobry zawód i lepsze życie. Poradniki wiele miejsca poświęcają również konieczności stworzenia dziecku optymalnych warunków do pracy. Opis postępowania z dzieckiem, które rodzice chcą wychować na małego geniusza, zawiera szczegółową listę sposobów motywowania, karcenia i nagradzania, osadzoną w dyskursie psychologicznym.

$\mathrm{Z}$ wątkiem tym powiązany jest dyskurs ekonomiczny, obecny w artykułach, gdzie zamiast o wychowaniu, mówi się o inwestycji w rozwój lub inwestycji $\mathrm{w}$ przyszłość dziecka. Osiągnięcia małych geniuszy podlegają wycenie rynkowej. W artykule Dziecięce wynalazki warte miliony! możemy przeczytać:

11 Wunderkind, czyli dziecko $z$ niespodzianka, 14.03.2013; http://kobieta.onet.pl/dziecko/maledziecko/wunderkind-czyli-dziecko-z-niespodzianka/hvmxf. 
Potencjał dzieci jest doskonale znany dorosłym, którzy działają na polu innowacyjności. Stąd liczne projekty i konkursy skierowane do dzieci i młodzieży. Część z dziecięcych wynalazków także w Polsce trafia do urzędu Patentowego. Jak czytamy na stronie www.innowacje2009.pl: „Dziecięce pomysły często zaskakują swoją prostotą i niekonwencjonalnym podejściem do rozwiązania problemów, a szczególnie tych, które dotyczą życia codziennego (...)"12.

Wynalazki małych geniuszy podlegają zatem podobnej logice jak wynalazki dorosłych naukowców, co włącza do dyskursu wychowania małego geniusza, opartego na idei nieskrępowanego rozwoju, element logiki rynku. Inwestycja w dziecko staje się tym samym opłacalna.

\section{Profesjonalizacja rodzicielstwa}

Jak zauważa Franciszek Adamski, każdy typ rodziny można analizować w kontekście wewnątrzrodzinnym, a więc $\mathrm{w}$ aspekcie określonego modelu rodziny, na który składają się wyobrażenie o małżeństwie, stosunki i powiązania wewnątrzmałżeńskie, relacje rodzice - dzieci, praca zarobkowa rodziców, potrzeby i dążenia kulturalne oraz uznawany system wartości (Adamski, 1991: 47-57). Niewątpliwie, aspekty te składają się na funkcjonujący społecznie, dominujący wizerunek rodziny oraz rodziców, będący historycznie oraz kulturowo zmiennym konstruktem.

Model rodziny, jaki wyłania się z analizy dyskursu wychowania małego geniusza, należy niewątpliwie do średniej lub wyższej klasy społecznej, charakteryzującej się wysokim kapitałem kulturowym. Rodzice są na tyle wszechstronnie wykształceni, aby rozwijać w dzieciach talent muzyczny czy plastyczny poprzez użycie różnego rodzaju technik malarskich, rozmawiać z nimi w języku obcym czy też wykonywać wspólnie proste eksperymenty chemiczne.

Rodzice przedstawieni w analizowanych artykułach sprawują nad dzieckiem ciągłą opiekę, znajdując się tym samym poza kontekstem współczesnych przemian mikro- i makroekonomicznych, warunkujących między innymi migracje zarobkowe czy też nowe strategie opieki nad dzieckiem. Jak wykazują badania z zakresu pedagogiki i socjologii, współcześnie mamy do czynienia z powstawaniem szeregu nowych strategii rodzicielstwa, co związane jest ze zwiększeniem widoczności określonych zjawisk społeczno-kulturowych, zmianami charakteru relacji międzyludzkich, zarówno w przypadku związków formalnych, jak i nieformalnych, a także zmianami w zakresie kultury pracy oraz wzrostem roli migracji (zob. Hondagneu-

${ }^{12}$ Dziecięce wynalazki warte miliony!, http://dzieci.pl/kat,1024265,title,Dzieciece-wynalazki-wartemiliony,wid,13224117, wiadomosc.html?_ticrsn=5\&smgputicaid=612d68. 
-Sotelo, Avila, 1997; Jaźwińska, Okolski, 2001; Urbańska, 2010). Analizowane poradniki promują model rodziny nuklearnej, składającej się z dwojga rodziców i dziecka, wokół którego koncentruje się całość ich oddziaływań.

W dyskursie wychowania małego geniusza mamy do czynienia z rezydencjalnym modelem opieki, realizowanej w sposób zbliżony do pracy zawodowej. Wyróżnia się przede wszystkim zjawisko profesjonalizacji rodzicielstwa, które, jak zauważa Philippe Noens, polega na wytworzeniu potrzeby ciągłego rozwoju, zmierzającego do profesjonalizacji działań rodziców ${ }^{13}$. W dyskursie profesjonalizacji rodzice czerpią $\mathrm{z}$ wiedzy ekspertów, dążąc do udoskonalenia swoich działań wychowawczych. Stają się również w pełni odpowiedzialni za szczęście, dobrostan i rozwój swoich dzieci, w związku z czym znajdować powinni się w ciągłej czujności wobec nadarzających się szans i zagrożeń. Rodzicielstwo staje się relacją typu „jeden na jeden”, zawiązywaną pomiędzy rodzicem oraz dzieckiem, które postrzegane jest jako człowiek mający potrzeby rozwojowe. Rodzicielstwo w takim ujęciu zamyka się w pojedynczej relacji, w której nie uczestniczą inni aktorzy (członkowie rodziny, szkoła, rówieśnicy) ${ }^{14}$. Stefan Ramaekers i Judith Suissa zwracają wręcz uwagę, że o profesjonalizacji roli rodziców świadczą nowe formy językowe. W języku angielskim funkcjonuje czasownik to parent oraz powstały od niego rzeczownik parenting, co symbolicznie pokazuje, że bycie rodzicem staje się czynnością, którą należy opanować, aby należycie wypełnić swoje obowiązki (Ramaekers, Suissa, 2010). Warto zauważyć, że słowo to, jako zapożyczenie, funkcjonuje w języku polskim i używane jest na określenie czynności bycia rodzicem. Słowo partneting używane jest też często w odniesieniu do popularnych źródeł wiedzy - portali internetowych (parenting.pl), czy blogów (blogi parentingowe).

$\mathrm{W}$ analizowanym materiale profesjonalizacja rodzicielstwa widoczna jest przede wszystkim poprzez ujęcie całokształtu relacji pomiędzy dzieckiem a rodzicem w kategoriach efektywności oddziaływań wychowawczych. Wychowanie jest tutaj zadaniem, które realizowane może być według określonego scenariusza w celu osiągnięcia konkretnego celu, jakim jest sukces dziecka. Celowi temu podlega każdy aspekt wychowania dziecka: zabawa, spacer, nauka, relacje pomiędzy rodzicami a dzieckiem.

${ }^{13}$ P. Noens, The Family as "Gathering": Re-Visiting the Pedagogical Dimension of Parenting in View of the Socio-Material Turn, Philosphy of Education Society in Great Britain, Annual Conference, New College Annual Conference 2010;

http://www.philosophy-of-education.org/uploads/2014\%20Conference/Papers/Noens.pdf (dostęp: 02.06.2014 r.).

${ }^{14}$ Ibidem. 
Na podstawie analizowanych artykułów wysnuć można wniosek, że sukces wychowawczy, który jest celem wychowania, może być wyłącznie rezultatem zastosowania procedur, które polecają poradniki.

(...) ważne jest, by znać zasady stworzone przez amerykańskiego psychologa: a) Entuzjazm, b) Dobrana pora na naukę liczenia, c) Bezwzględny zakaz sprawdzania efektów, d) Zawsze kończymy, zanim maluch zacznie się nudzić, e) Po każdej „nauce” chwalimy maluszka (bez względu na to, czy ma 2 tygodnie czy 2 lata). Metoda polega na systematycznym, częstym pokazywaniu dzieciom kart, na których najpierw namalowane są kropki, potem cyfry i liczby ${ }^{15}$.

W dyskursie poradników rodzice skonfrontowani zostają z wiedzą specjalistyczną. W analizowanych portalach cała wiedza na temat wychowania małego geniusza oparta jest bowiem na diagnostyce ekspertów. Idąc dalej, stwierdzić można, że staje się ona w całości polem działania zewnętrznych ekspertów, natomiast usunięta z niego zostaje rodzina, której kompetencje są ignorowane. Rodzina zostaje wykluczona $z$ procesu produkcji wiedzy na temat wychowania, a tym samym $\mathrm{z}$ całego procesu.

Rodzice realizujący sprofesjonalizowany program wychowawczy muszą znaleźć złoty środek pomiędzy wsparciem emocjonalnym a racjonalnym kierowaniem zachowaniami dziecka. Sprofesjonalizowane wsparcie dziecka, podobnie jak każda inna czynność związana $\mathrm{z}$ wychowaniem, nie jest bezcelowe. Realizowane jest $\mathrm{w}$ pełnym zakresie, przy równoczesnym poszanowaniu marginesu wolności (i rozwoju) dziecka:

Pamiętaj o złotej zasadzie - odtwarzanie zabija twórczość! Spraw, by dziecko zawsze odczuwało Twoją obecność oraz gotowość do pomocy i jednocześnie wzbraniaj się przed kierowaniem dzieckiem czy też podpowiadaniem mu rozwiązań, do chwili, gdy samo o to poprosi. Wspieraj w samodzielnym dochodzeniu do celu, zachęcając do szukania nowych, nieznanych dróg. Bądź przy tym cierpliwy i wyrozumiały. Może okazać się, że Twoje dziecko jest o wiele mądrzejsze, niż Ci się wydawało, i że niepotrzebnie wyręczałeś je w udzielaniu odpowiedzi na zadawane pytania ${ }^{16}$.

W dyskursie poradników emocjonalne relacje z dzieckiem podporządkowane są celowi wychowania, w związku z tym należy je kontrolować. Zgodnie z przytoczonym fragmentem, rodzic nie może być po prostu obecny przy dziecku, musi to robić w sposób przemyślany. W wychowaniu małego geniusza nawet najbardziej

\footnotetext{
${ }^{15}$ Jak nauczyć niemowlaka liczyć?, op. cit.

${ }^{16}$ Jak wychować geniusza?, op. cit.
} 
spontaniczne zachowania stają się częścią technologii wychowania, w ramach której zachodzi zarządzanie emocjami.

W tym kontekście warto przytoczyć zjawisko unaukowienia relacji rodzic dziecko, wyróżnione przez Stefana Ramaekersa i Judith Suissę. Według nich, współczesne rodzicielstwo naznaczone jest niepewnością i strachem przed odpowiedzialnością. Bycie rodzicem przedstawiane jest jako zadanie, do którego można być dobrze lub źle przygotowanym (Ramaekers, Suissa, 2010). To przekłada się na zoperacjonalizowanie wychowania w serię zadań, na których wypełnianiu można się skoncentrować. Lęk przed byciem rodzicem staje się lękiem przed złym wypełnieniem zadania (Ramaekers, Suissa, 2010).

Wydaje się jednakże, że zaobserwowane przez badaczy zjawiska lęku i niepewności rodziców są nie tyle przyczyną, co skutkiem oddziaływań zewnętrznych, związanych przede wszystkim z dyskursywnym konstruowaniem społeczeństwa i technologiami siebie. Sprofesjonalizowane rodzicielstwo wpisuje się bowiem $\mathrm{w}$ ciąg podobnych strategii retorycznych, ujawniających się również w innych sferach życia, takich jak profesjonalizacja opieki czy profesjonalizacja macierzyństwa (zob. Charkiewicz, 2009; Urbańska, 2010).

Ważnym aspektem profesjonalizacji rodzicielstwa jest genderowe zróżnicowanie tego procesu. W analizowanych artykułach oboje rodzice zajmują się dzieckiem, co, zdawałoby się, przedstawiane jest wbrew stereotypowemu postrzeganiu kobiet jako statystycznie częściej sprawujących opiekę. Głębsza analiza pokazuje jednak, że nie jest to promowanie partnerskich relacji pomiędzy rodzicami, a dyskurs poradników jest tylko pozornie genderowo neutralny. W dyskursie rodzicielstwa kulturowa rola kobiet zostaje raczej uniewidoczniona, co odzwierciedlone zostaje w wyraźnym podziale ról wychowawczych. Mimo iż przekaz kierowany jest do obojga rodziców, instrukcje dotyczące żywienia i pielęgnacji odnoszą się głównie do matek, na przykład:

O prawidłowy rozwój intelektualny warto zadbać już wtedy, kiedy dziecko rozwija się w łonie matki, bo to właśnie wówczas następuje kształtowanie się układu nerwowego i mózgu. Całkowita ilość komórek nerwowych wytwarzana jest właśnie w życiu płodowym i jeśli nie będą one używane - zanikną. Każdy z nas ma świadomość, że dzieci potrzebują zróżnicowanej diety, bogatej w wiele różnych składników. Dlatego te wszystkie kwasy tłuszczowe i minerały, o których pisaliśmy, powinny znaleźć się już w diecie kobiet ciężarnych i później podczas karmienia maleństwa ${ }^{17}$.

${ }^{17}$ Dieta przyszłego geniusza, op. cit. 
To jeden w wielu przykładów pokazujących, że zgodnie z analizowanym materiałem to kobiety odpowiedzialne są za prawidłowy biologiczny rozwój małego geniusza. Poprzez swoją rolę opiekuńczą włączone zostają w projekt rozwoju, o którym mowa była wcześniej, stając się jego wykonawczyniami. Ich rolą jest zapewnienie odpowiednich warunków żywieniowych, pielęgnacji i opieki. Ojcowie natomiast $\mathrm{w}$ analizowanych artykułach przedstawiani są głównie w kontekście zabawy i nauki, co dodatkowo podkreśla przytaczanie ich tytułów naukowych, zawodów oraz zainteresowań, które mogą dzielić z dzieckiem, na przykład:

Rodzice dziewczynki szybko zauważyli, że jest bystra, ale sądzili, że to dzięki wcześnie rozpoczętej nauce czytania. Jednak gdy ojciec Heidi - wykładowca na Uniwersytecie w Southampton - dał jej do rozwiązania test na inteligencję przygotowany dla dzieci, okazało się, że wyniki przekroczyły dostępną skalę ${ }^{18}$.

Celowe zestawienie powyższych fragmentów pokazuje wyraźny podział zadań wychowawczych pomiędzy kobietami i mężczyznami, pokrywający się ze znanym kulturowym podziałem na sferę publiczną i prywatną, który opisuje Sherry Ortner. Zgodnie z nim, role kobiet kulturowo przypisane są do sfery prywatnej, domowej, związanej z pielęgnacją i opieką, role męskie są natomiast publiczne, wiążą się $z$ reprezentacją i głosem. Podział ten wywodzi się od dialektycznej opozycji pomiędzy naturą i kulturą, który w kontekście płci interpretowany jest jako przypisanie kobiet do dzikiej, popędliwej natury, a w konsekwencji - do sfery domowej, prywatnej, mężczyzn natomiast do kultury i cywilizacji (Ortner, 1982). W analizowanym materiale podział ten jest wyraźnie widoczny poprzez przydzielanie matce i ojcu odrębnych zdań w projekcie wychowania geniusza. Zadania kobiet dotyczą zatem opieki, żywienia czy dbania o zdrowie i ciało dziecka, podczas gdy ojcowie dbają o rozwój intelektualny oraz uczenie się dziecka podczas zabawy. Związane być to może $\mathrm{z}$ silnie zaakcentowaną $\mathrm{w}$ polskich poradnikach i dyskursie eksperckim obecnością modelu rodziny opartego na schemacie Talcotta Parsonsa, przypisującym matce rolę ekspersyjno-integracyjną, ojcu natomiast instrumentalno-przystosowawczą (Parsons, 1969).

Kolejną kwestią związaną z podziałem ról są upomnienia, jakie dawane są rodzicom. Zarówno ojcom, jak i matkom zwraca się uwagę na niebezpieczeństwo przemęczania dziecka nadmiarem nauki i przenoszenia na nie własnych ambicji. To jednak matki karcone są wprost za nieodpowiednie względem dziecka zachowanie. Przyjrzyjmy się następującemu przykładowi:

${ }^{18}$ Mali geniusze, op. cit. 
Kobiety mają pranie mózgu, wmówiono im, że mają być takie, a nie inne. Dziecko ma być najładniejsze, najzdrowsze i pierwsze z całej wsi siadać na nocnik. W wieku czterech lat chodzić na angielski i origami, a w szkole mieć same piątki - pisze ledzeppelin3 na forum eDziecko.pl. W mediach wmawia się kobietom, że źle wychowują dzieci, za dużo lub za mało nagradzają, że je za bardzo od siebie uzależniają, nie stosują metody Gordona (...). Tym samym pragną z dziecka uczynić obiekt podziwu i dumy, bo wtedy spadnie na nie część splendoru: „Zobaczcie, wszystko mu poświęciłam, ale za to jak wychowałam dziecko"19.

W przytoczonym tu fragmencie artykułu cytowana jest wypowiedź z forum internetowego, która służy autorce tekstu jako ilustracja tezy o nadmiernych ambicjach rodziców. Wyraźnie zarysowane jest rozróżnienie pomiędzy matkami a ekspertami wypowiadającymi się w mediach oraz, co zaskakujące, pomiędzy matkami a ich dziećmi. Wyraźnie widoczny jest tutaj również wizerunek nadopiekuńczej i zbyt ambitnej matki, która chce zrekompensować sobie poświęcenie dla dziecka, sięgając po część jego sukcesu. Podobna teza pojawia się w kolejnym fragmencie:

To naturalne, że jesteś dumna z dokonań swojego dziecka. Kiedy w jednym miejscu znajduje się kilka matek, atmosfera natychmiast gęstnieje i nieuchronnie pojawia się duch rywalizacji. W zależności od grupy, licytacja może dotyczyć zaangażowania i efektów albo zdystansowania i zwisa pospolitego. - Pamiętam, jak pierwszy raz spotkałam się z żonami kolegów mojego męża z pracy - wspomina Justyna, matka dwójki przedszkolaków (...). Odniosłam wrażenie, że te spięte mamy znalazły nową formę autoekspresji - definiowały siebie i swoje dokonania przez wybitne postępy swoich dzieci $(\ldots)^{20}$.

W przytoczonym fragmencie, podobnie jak we wcześniejszym, widoczny jest wątek zarzutów wobec matek, które nadmiernie utożsamiają się z sukcesami swoich dzieci. Wydaje się, że oba cytaty w jasny sposób odnoszą się do diagnozowanego przez Sylwię Urbańską stereotypowego postrzegania kobiet jako rozchwianych emocjonalnie oraz nawiązują do pojawiającego się w poradnikach wątku wyciszania emocji matek. Przykładanie specjalnej wagi do dyscyplinowania matek świadczyć może o powszechnym kulturowym przekonaniu, że negatywne emocje matki są transmitowane na dziecko (Urbańska, 2010: 29).

Ciekawym wątkiem jest przypisywanie negatywnych cech rodzicielstwa specyfice kulturowej oraz tak zwanemu charakterowi narodowemu:

${ }^{19}$ J. Rokicka, Moje dziecko jest najlepsze!, 27.09.2011; http://www.edziecko.pl/rodzice/1,79361,1030 3312,Moje_dziecko_jest_najlepsze_html.

${ }^{20}$ O. Długołęcka, A moje dziecko to, czyli niekończąca się licytacja matek, 20.07.2013; http://m. edziecko.pl/edziecko/1,133498,11372901,A_moje_dziecko_to_czyli_niekonczaca_sie_licytacja.html. 
Polacy ponad wszystko pragną dziecka idealnego, to znaczy lepszego od innych (...). Doszukujemy się u innych dzieci wad, słabych punktów, próbujemy złapać na błędzie. Z czego wynika ta obsesja porównywania, rywalizowania i deprecjonowania innych dzieci przez polskie matki i ojców? (...) Na pewno jako rodzice mamy kompleksy. Często wychowywaliśmy się w czasach komunizmu, gdy wiele możliwości rozwoju, gadżetów, zajęć i podróży było dla nas nieosiągalnych. Nie zawsze mogliśmy uczyć się języków obcych, rzadko studiować za granicą, jeździć na zagraniczne warsztaty. Dlatego chcemy sobie to zrekompensować przez napięty grafik zajęć dodatkowych i sukcesy naszych dzieci, na które liczymy. W ten sposób sami czujemy się dowartościowani i spełniamy oczekiwania innych - czujemy się dobrymi rodzicami, gdy nasze dziecko przyćmiewa innych ${ }^{21}$.

W tym wypadku dyscyplinowanie emocji rodziców osadzone jest $\mathrm{w}$ dyskursie negatywnych stereotypów narodowych - kompleksów i braku życzliwości, które przypisywane są Polakom. Ta surowa diagnoza jest częścią popularnego w naszym kraju dyskursu piętnującego narodowe wady i przywary, w ramach którego Polacy przedstawiani są jako narzekający i pochmurni. Tego typu dyskursy odwołują się do kulturowej koncepcji narodu, w myśl której jego członków łączy wspólnota krwi, tradycji, religii, a także wspólny charakter narodowy, wynikający albo z urodzenia, albo ze wspólnych dla całego narodu warunków społeczno-kulturowych. $\mathrm{W}$ przytoczonym fragmencie te wspólne cechy wynikać mają $\mathrm{z}$ doświadczenia komunizmu, które wytworzyło w rodzicach poczucie braku oraz kompleksy, które starają się oni leczyć przy pomocy swoich dzieci.

Przytoczony fragment przywodzi również na myśl dyskursy transformacyjne związane $\mathrm{z}$ ideą modernizacji, zakładającą unowocześnienie poprzez przyjęcie modelu zachowań oraz modelu gospodarczego wzorowanego na państwach zachodnich.

Współczesne społeczeństwa zachodnie, zdawało by się, wyszły już poza dyskurs transformacji. Dotyczy to również państw postsocjalistycznych, które włączone w obieg globalnego kapitału przestały być wyłącznie imitatorami stylu życia oraz ładu gospodarczego społeczeństw zachodnich. Dyskurs ten dawno już przestał uwodzić oraz w wystarczający sposób tłumaczyć naszą rzeczywistość. Dlatego też zaskakuje obecność w ramach dyskursu wychowania małego geniusza właśnie elementów dyskursu modernizacyjnego, ujawniającego się w podkreśleniu procesu ciągłego doskonalenia, rozwijania i unowocześniania, przy równoczesnym wytykaniu narodowego zacofania, sięgającego aż do poziomu rodziny. Tym razem jednak to nie naród, ale rodzina musi się zmodernizować. Jest to wyraźne przeniesienie dyskursu instytucjonalnego oraz narodowego do sfery prywatnej.

\footnotetext{
${ }^{21}$ J. Rokicka, op. cit.
} 


\section{Rodzina jako podmiot przedsiębiorczy}

Dyskurs wychowania małego geniusza jest ciekawym przykładem włączenia dyskursu należącego do sfery prywatnej - dotyczy on przecież rodziny - w obręb dyskursu publicznego, dotyczącego wizji rozwoju społeczeństwa, a w jego ramach rodziny. Technologia wychowania małego geniusza odzwierciedla konkretny sposób myślenia o społeczeństwie, stając się częścią dyskursu przedsiębiorczego Ja.

Jak zauważa Urlich Bröckling, dyskurs przedsiębiorczego Ja opiera się na Foucaultowskim modelu konstruowania podmiotowości, zgodnie z którym w procesie tym na jednostkę oddziałuje szereg wewnętrznych i zewnętrznych czynników, wśród których są między innymi formy poznania, strategie organizacyjne i technologie siebie, jak również wzajemne oddziaływania pomiędzy jednostkami. W procesie „genealogii upodmiotowienia” Foucault odtwarza konstruowanie podmiotu, pytając, jakich rodzajów wiedzy użyto do mówienia o danym podmiocie oraz jakich technologii użyto, aby go ukształtować (Bröckling, 2005: 3).

Rekonstruując myśl Foucaulta, Bröckling zauważa, że sposób konstruowania przedsiębiorczego Ja ujawnił się w tekstach ekonomicznych Szkoły Chicagowskiej po 1945 roku i był nową formą racjonalności, opartej na konkurencyjności jako ogólnym modelu ludzkiego działania w każdej sferze życia. Przekładając przedstawiane jako uniwersalne prawa ekonomiczne na jednostkę, w dyskursie tym konstruuje się podmiot jako przedsiębiorcę samego siebie: „Jednostka występuje tu jako ekonomiczna instytucja, której egzystencja, podobnie jak działalność przedsiębiorstwa, uzależniona jest od wyborów spośród wielu możliwych opcji. Na cokolwiek on czy ona się nie zdecyduje, zawsze możliwa jest zmiana i wybór innego kursu działania. Wychodząc z takich założeń, można przyjąć, iż jednostka zawsze będzie kierować się swoimi upodobaniami. Przedsiębiorcze Ja to jednostka, która bezustannie podejmuje decyzje, homo oeconomicus, który w każdym momencie życia zajmuje się alokacją rzadkich zasobów na konkurencyjne cele” (Bröckling, 2005: 3).

Wydaje się, że w analizowanym dyskursie mamy do czynienia z przeniesieniem logiki podmiotu przedsiębiorczego Ja na rodzinę, która dąży do maksymalizacji swoich korzyści w ramach rynku, na którym funkcjonuje. Rodzina dokonuje w tym dyskursie szeregu zaplanowanych działań, oddziaływań wychowawczych, które są inwestycją w projekt rozwoju dziecka. Rodzina jest zatem, mówiąc językiem Foucaulta, przedsiębiorcą samej siebie.

Ujęcie rodziny jako podmiotu przedsiębiorczego odsuwa na dalszy plan emocjonalną funkcję rodziny, czyniąc z niej raczej podmiot interesów. Charaktery- 
styczne jest, że w analizowanych artykułach, które stały się podstawą rekonstrukcji dyskursu wychowania małego geniusza, nie padają słowa o wsparciu dziecka, miłości czy przyjemności spędzania razem z nim czasu. Wychowanie małego geniusza jest procesem technologicznym, w którym nie ma miejsca na czynności niezwiązane z osiągnięciem celu. Dziecko staje się tu, jak nazywa to Foucault, „kompetentną maszyną" (competence machine) (Bröckling, 2005: 3), a w przyszłości - przedsiębiorcą samego siebie. Dzisiaj jednak, póki jest niesamodzielne oraz podatne na wpływ, należy je rozwijać oraz dostosowywać do wymogów rynku.

\section{Zakończenie}

Analiza dyskursu wychowania małego geniusza zawartego w popularnych internetowych poradnikach dla rodziców ujawnia funkcjonujące społecznie wzory rodziny pojmowanej jako samozarządzająca się, racjonalna jednostka, kierująca się logiką inwestycji, w tym wypadku - wychowawczej.

Dyskurs geniusza, mimo iż wywodzi się z kręgu wysokiej kultury i sztuki, współcześnie stał się powszechny i ogólnie dostępny. Sam geniusz natomiast już dawno przestał być związany z niedostępną łaską o boskiej proweniencji, spotykającą wyłącznie elity. Współczesny geniusz urodzić może się wszędzie, od kompetencji jego rodziców należy natomiast rozpoznanie go oraz zapewnienie mu odpowiednich warunków rozwoju i kapitału kulturowego. $\mathrm{Z}$ analizy dyskursu wychowania małego geniusza wyraźnie wynika bowiem, że to jego rodzice muszą być zdyscyplinowani na każdym polu, aby prawidłowo wypełniać powierzone im zadania. Nie mogą popełnić błędu, gdyż oznacza to, iż zmarnują szansę na rozwój swojego dziecka.

W analizowanym dyskursie wyraźnie wyróżnia się zabieg profesjonalizacji rodzicielstwa, którego celem jest wychowanie dziecka wysokiej jakości. Rodzice pełnią tu jedynie rolę wykonawczą. W całkowicie skonstruowanym i kontrolowanym świecie małego geniusza nie ma dla nich miejsca. Przestają uczestniczyć w budowaniu wiedzy na temat własnego rodzicielstwa. Wiedza ta natomiast zdominowana zostaje przez dyskurs ekspercki. Proces wychowania staje się zatem wyłącznie polem działalności ekspertów, którzy produkują całość niezbędnej wiedzy na temat oddziaływań pedagogicznych.

$\mathrm{W}$ analizowanych portalach parentingowych dyskurs wychowania małego geniusza jest społecznie zdekontekstualizowany. Wynika z niego, że każda rodzina, niezależnie od statusu społecznego, sytuacji prawnej oraz kryterium rezydencjal- 
ności, może zapewnić dziecku takie same warunki do rozwoju zdolności. Dyskurs ten kierowany jest do wszystkich rodzin, każdej z nich stwarzając złudną nadzieję, że może ona, przy pomocy opisanych metod, zapewnić swojemu dziecku lepszą przyszłość. W tym celu rodzice muszą zastosować się do wskazówek ekspertów. Jednakże przedstawione w analizowanym dyskursie, pozbawione kontekstów społecznych modele wychowana nie uwzględniają zróżnicowania rodzin, ich różnych potencjałów i kapitałów społecznych.

Co więcej, złudna dostępność posiadania dziecka-geniusza jest uwodząca. Bazuje na zrozumiałej chęci do zapewnienia dziecku jak najlepszej przyszłości. Apelując do emocji, dyskurs ten równocześnie dyscyplinuje rodziców, przedstawiając wychowanie jako uporządkowany proces technologiczny. $\mathrm{W}$ praktyce jednak rola rodziców sprowadza się do wykonywania poleceń oraz nabywania kolejnych produktów edukacyjnych, które sprawią, że będą mogli oni aspirować do narzuconego wzorca.

Przeanalizowany przeze mnie dyskurs wychowania małego geniusza w internetowych portalach dla rodziców - zanurzony w neoliberalnym rozumieniu pojęć geniusza i talentu oraz odwołujący się do pojęć związanych z modernizacją, zmianą czy unowocześnieniem - jest przede wszystkim dyskursem indywidualnego sukcesu rodziny, mierzonego wypełnieniem zadań wynikających $z$ dokładnie zaplanowanego procesu wychowania. Zdefiniowany poprzez dyskursy biologicznej odmienności, naukowości i profesjonalizacji, wydaje się próbą foucaultowskiego ujarzmienia podmiotowości rodziny.

Podsumowując, warto też zauważyć, że dyskurs ten jest doskonałym przykładem na to, jak silnie instytucja rodziny powiązana jest z systemem społecznym, a tym samym zależna od społecznych i kulturowych relacji władzy.

\section{Literatura}

Adamski F. (1991). Wychowanie w rodzinie. Kraków.

Allen D.E., Anderson P.F. (1994). Consumption and Social Stratification: Bourdieu's Distinction. „Advances in Consumer Research", vol. 21.

Andrukowicz W. (2012), By dziecko było geniuszem. Wprowadzenie do edukacji komplementarnej. Kraków 2012.

Bauman Z. (2007). Plynne czasy. Życie w epoce niepewności. Warszawa 2007.

Bröckling U. (2003). Upłciowienie przedsiębiorczego Ja. „Distinktion”, nr 11, s. 7-25.

Charkiewicz E. (2009). Gender i opieka w reformie systemu ochrony zdrowia. Biblioteka On-Line Think Tanku Feministycznego. 
Dyrda B. (2000). Syndrom Nieadekwatnych Osiagnięć jako niepowodzenie szkolne uczniów zdolnych: diagnoza i terapia. Kraków.

Fairclough N., Duszak A. (2008). Krytyczna analiza dyskursu - nowy obszar badawczy dla lingwistyki i nauk społecznych. [W:] Krytyczna analiza dyskursu. Interdyscyplinarne podejście do komunikacji społecznej, red. N. Fairclough, A. Duszak. Kraków, s. 7-29.

Florida R. (2010). Narodziny klasy kreatywnej, przeł. T. Krzyżanowski, M. Pękała. Warszawa.

Ghandi L. (2008). Teoria postkolonialna: wprowadzenie krytyczne, przeł. J. Serwański. Poznań.

Harris D. (2013). Leisure and Higher Education. [W:] Routledge Handbook of Leisure Studies. Red. T. Blackshaw. New York, s. 413-422.

Hondagneu-Sotelo P., Avila E. (1997). "I'm here, but I'm there": The Meanings of Latina Transnational Motherhood. „Gender \& Society”, no. 11, s. 548-571.

Jaźwińska E., Okolski M. red. (2001). Ludzie na huśtawce. Migracje między peryferiami Polski i Zacho$d u$. Warszawa.

Kasperski E. (2012). Romantyzm i poprzednicy. Wokół dyskursów prefundacyjnych. „Świat Testów. Rocznik Słupski”, nr 10, s. 5-22.

Klus-Stańska D. (2008). Między wiedza a władzą. Dziecięce uczenie się w dyskursach pedagogicznych. [W:] Rozwijanie zdolności uczenia się. Wybrane konteksty i problemy. Red. E. Filipiak. Bydgoszcz, s. 59-73.

Kosyra-Cieślak T. (2013). Praca z uczniem zdolnym na lekcjach języka polskiego i zajęciach pozalekcyjnych. Warszawa.

L. Nochlin (2007). Dlaczego nie było wielkich artystek? „Unigender”, nr 1(3).

Limont W., Cieślikowska J., Jastrzębska D. red. (2012). Zdolni w szkole, czyli o zagrożeniach i możliwościach rozwojowych uczniów zdolnych. Poradnik dla nauczycieli i wychowawców. Warszawa.

Michałowska D.A. (2013). Neoliberalizm i jego (nie)etyczne implikacje edukacyjne. Poznań.

Ortner S.B. (1982). Czy kobieta ma się tak do mężczyzny, jak „natura” do „kultury”? [W:] Nikt nie rodzi się kobietą. Red. T. Hołówka. Warszawa, s. 112-141.

Parsons T. (1969). Struktura społeczna a osobowość, przeł. M. Tabin. Warszawa.

Ramaekers S., Suissa J. (2010). The Scientization of the Parent-Child Relationship. [W:] Negotiating Childhood. Red. L. Hopkins [et al.]. Oxford, s. 179-191.

Rousseau J.J. (1955). Emil, czyli o wychowaniu, przeł. W. Husarski, t. 1-2. Wrocław.

Sancar C., Sancar M. (2012). Neoliberal Mechanisation of Education. „TOJET: The Turkish Journal of Educational Technology", vol. 11, no 3, s. 246-254.

Skórczewski D. (2010). Kilka myśli o romantyzmie i Słowackim z postkolonializmem $w$ tle. „Słupskie Prace Filologiczne. Seria: Filologia Polska", nr 8, s. 117-143.

Sztop-Rutkowska K. (2007). Meandry dialogu. Polacy i Żydzi w dyskursie prasowym międzywojennego Białegostoku. „Przegląd Socjologii Jakościowej”, nr 2(3), s. 63-81.

Urbańska S. (2010). „Cała Polska liczy eurosieroty”. Panika moralna i płeć w wykluczeniu oraz stygmatyzacji rodzin migrantów. „Kultura i Społeczeństwo”, nr 3, s. 61-88.

Urbańska S. (2010). Profesjonalizacja macierzyństwa jako proces odpodmiotowienia matki. Analiza dyskursów poradnika „Twoje Dziecko” z 2003 i 1975 roku. Biblioteka On-Line Think Tanku Feministycznego.

Wagg S. red. (2005). Cricket and National Identity in the Postcolonial Age. New York.

Zierkiewicz E. (2011). Poradnik jako podręcznik życia. Krótka refleksja na temat historii gatunku. [W:] Podręczniki i poradniki. Konteksty. Dyskursy. Perspektywy. Red. M. Chomczyńska-Rubacha. Kraków, s. 109-129. 


\section{Źródła internetowe:}

Noens P., The Family as "Gathering": Re-Visiting the Pedagogical Dimension of Parenting in View of the Socio-Material Turn. Philosphy of Education Society in Grait Britain, Annual Conference, New College Annual Conference 2010; http://www.philosophy-of-education.org/uploads/2014\%20 Conference/Papers/Noens.pdf (dostęp: 2.06.2014 r.).

Onet Dziecko, Dzieci.pl i eDziecko.pl na czele, w dót Rodzice.pl i Dobramama.pl (TOP15 serwisów parentingowych), Wirtualne Media, 16.05.2014 r.; http://www.wirtualnemedia.pl/artykul/onetdziecko-dzieci-pl-i-edziecko-pl-na-czele-w-dol-rodzice-pl-i-dobramama-pl-top15-serwisowparentingowych (dostęp: 18.05.2014 r.).

Serwisy parentingowe w Polsce: zawartość serwisów, popularność wśród internautów, profil użytkowników. Polskie Badania Internetu, luty 2011; http://pbi.org.pl/raporty/Serwisy_parentingowe.pdf (dostęp: 01.10.2014 r.).

\section{Materiał empiryczny:}

Artykuły z internetowych poradników dla rodziców: Onet Dziecko, Dzieci.pl oraz e-dziecko.pl z lat 2009-2013.

\section{Family as Enterprising Subject - Critical Analysis of the Infant Prodigy Discourse in Internet Portals for Parents}

\section{Summary}

The aim of this paper is to analyse the infant prodigy discourse in popular Polish internet portals for parents.

The infant prodigy is a well-established concept, historically derived from a concept of genius. Contemporary it is gaining increasing popularity in educational discourse. It is broadly used in guidebooks for parents, kids products commercials, as well as in curricula and educational materials.

In terms of methodology I have used Critical Discourse Analysis. The overall objective of Critical Discourse Analysis is to investigate the relation between texts, discourses and social structures, in order to explain the ideological dominance of some suppressive discourses in society. I have followed Norman Fairclough and Anna Duszak approach, considering CDA as analysis of rhetoric strategies, involved in construction of dominating discourses, as well as identity construction processes.

In my paper I have identified few features characterizing the analysed discourse.

The first distinguished feature is rationality and application of the notion "progress". The texts promote development in all spheres of life, encouraging parents to take advantage of every opportunity they have to educate children.

The gifted child represented in the analysed material is pictured as active, curious and willing to learn during every performed activity. He or she constantly develops supported by parents, who are aware of the importance of progressing.

The infant prodigy discourse is influenced by medicalization and scientization. Scientific vocabulary, mostly related to medicine, psychology and neurology is used. A gifted child is presented as biologically different from other children, that can be interpreted as discursive process of racialization. 
As far as parenthood is concerned, a phenomenon of professionalization may be distinguished. As Philipe Noens put it "Parents are conceived as being in need of advice and expertise about childrearing, even to the extent that they are expected to professionalize themselves. Alongside this, parents are addressed as being responsible for acting on their child's behalf - this being, the child's well-being, happiness, optimal emotional development, and so on; words that point to the presence of the language of developmental psychology in the way we think and talk about childrearing".

In the analysed material professionalization is manifested by recognition of a child and parent relationship in terms of the effectiveness of upbringing. Education is perceived as a task that can be performed according to particular scenario in order to achieve specific objectives. Every aspect of upbringing, including playing, walking, learning, and relationships between parents and a child, is subjected to achieving the objectives.

Moreover, emotional relation between parents and a child should be controlled, so as not to undermine the process of upbringing. Parents are disciplined, and told to restrain their emotions and ambition. This particularly relates to mothers, who are presented as emotionally unpredictable and accused of treating their child's successes as compensation.

A differentiation of male and female gender roles is identified. Mothers are presented as belonging in the private sphere. Their tasks are related to care and nutrition, while fathers are related to fun and education.

Knowledge about upbringing is produced solely by experts. Parents become alienated from knowledge about parenthood, and are expected to follow the directions given by experts.

The other identified feature is scientization of parent-child relation, which means conceptualizing the relation in the framework of developmental psychology. The scientization of discourse leads to creating a discursive representation of a good parenting, "aimed at ameliorating social, emotional and developmental problems".

Parents negative impact on upbringing is also related to national stereotypes and social transition and modernization discourse. Parents are presented as influenced by the experience of communism, and encouraged to change their behavior, and adapt to new reality.

A picture of a family, presented in the analyzed material, is defined by universal categories of quality of the appropriateness of parental choices and actions. It is a normative model of a nuclear middleclass family, taken out of social context, and does not including contemporary family models, such as patchwork families, and new strategies of care related to migration or work intensification.

The family model represented in the infant prodigy discourse, as well as the preferred upbringing model, may be related to the notion of self-entrepreneurship. The idea comes from Michel Foucault theory and relates to the identity construction processes. Self-entrepreneurship means creating individual as self-responsible economic entity, making rational decisions considering his or her life. The individual may be described as homo oeconomicus, guided by the logic of concurrency. Consequently, a family presented in the analyzed material, tends to maximize its benefits within the market, and, for this purpose, it performs the planned activities, perceived as investment opportunity.

The presented model of a family relationship neglects its emotional function. What is more, the analyzed texts, which have become a basis for reconstruction of the infant prodigy discourse, do not mention, emotional bonds or emotional security. Parenting is reduced to performing solely activates related to achieving the planned goals. Following Foucault, it may be said that the analyzed discourse of the infant prodigy, a gifted child becomes "a competence machine", and, a succeeding entrepreneur of the self. 